\title{
Trajectories of (Non)Belief in the Scientific Community: The Case of Polish and Ukrainian Natural Scientists
}

\author{
Maria Rogińska ${ }^{1}$ (D)
}

Received: 19 June 2018 / Accepted: 7 September 2019 / Published online: 16 September 2019

(c) The Author(s) 2019

\begin{abstract}
The article contributes to the discussion on the secularizing impact of science in modern societies. The starting point of the research is sociological data that shows lower religiosity of scientific communities in comparison to the general population in various countries. This might indicate that science does exert a secularizing force on modern ideologies. The explanatory hypotheses of this phenomenon are, however, ambiguous and predominantly concern Western countries. Based on 100 in-depth interviews with physicists and biologists from Central and Eastern Europe (Poland and Ukraine), it demonstrates the crucial role of cultural and historical context in the formulation of the (un)faith of the scientists. The scientific knowledge and participation in science as a social institution is more complementary than decisive in these processes, moreover, these factors play different roles in biographical trajectories of the Polish and Ukrainian natural scientists.
\end{abstract}

Keywords Secularizing impact of science $\cdot$ Religion $\cdot$ Physicists $\cdot$ Biologists · Biography $\cdot$ Central and Eastern Europe $\cdot$ In-depth interviews

\section{Introduction}

A belief that science contributes to the secularization of the Western societies has been one of the key philosophical and sociological discussions since the Age of Enlightenment. This belief is still present in debates on the theory of secularization. The former rests, as Jurgen Habermas explains, on several considerations, the first of which assumes that the "progress in science and technology promotes an anthropocentric understanding of the 'disenchanted' world because the totality of empirical states and events can be causally explained". Therefore, "a scientifically enlightened mind cannot be easily reconciled with the theocentric and metaphysical worldviews" (Habermas 2008). Sociological studies on the academia seem to

Maria Rogińska

mariaroginska@gmail.com

1 Uniwersytet Pedagogiczny im Komisji Edukacji Narodowej w Krakowie, Kraków, Poland 
confirm the diagnosis: scholars in the West are less religious than the general public (Leuba 1916, 1934; Roe 1952; Bello 1954; Vaughan et al. 1966; Larson and Witham 1998; Stark et al. 1996; Gross and Simmons 2009; Ecklund and Scheitle 2007; Ecklund 2010; Pew Research Center 2009; Bourget and Chalmers 2013). The question, however, concerns the true origin of this phenomenon, and more precisely the location of the social filter contributing to the selection of non-belief in the research community. Have the scholars been recruited from the irreligious families? Had the loss of faith occurred at the university? Is the science practiced by a mature researcher responsible for secularizing the research community? If the latter thesis was confirmed we would speak with more certainty about the impact science has on the secularization of societies.

Sociological data is not clear enough, and the vast body of research indicates each of the mentioned hypotheses may prove to be valid (see: Beit-Hallahmi 2015). At the same time the latest comparative studies show that, although scientists being less religious seems to be a global phenomenon, individual religious cultures formulate their own patterns of (non)religious worldviews. Moreover, the opinion that science and religion are conflicted is rather characteristic for Western countries, while scientists from India, Hong Kong or Taiwan generally think cooperation is possible. This shows that "religious tradition and regional context play an important role in the science-faith interface" (Ecklund et al. 2016).

Inter-cultural approach is particularly important in the context of our discussion on the theory of secularization, the western-centric character of which has been recently criticized. As many sociologists today agree, the conventional secularization thesis was focused on Western countries (Turner 2010, p. 651). Geographically, it was effective, as Peter Berger admits, only in Western and Central Europe (Berger 2008). Meanwhile, Jose Casanova says, it seems that the general secularization theory should not be applied to the cultures "with very different modes of structuration of the religious and the secular", and we must take into account various historical models of secularization (Casanova 2008, pp. 101-119).

In this respect, CEE has become of particular interest to the researchers (see, for example Pollack and Pickel 2007; Müller 2011). These societies went through a period of the state-imposed secularism, and after the fall of the communist regimes they experienced religious revival. Some researchers saw this phenomenon as supporting the erroneousness of the theory (Stark 1999). Others saw yet another face of the multi-dimensional concept of secularization (Barker 1998), the evidence of the ineffectively implemented coerced secularization (Froese 2004b) or an effect of a 'free market of religious services' (see Norris and Inglehart 2004; Froese 2004a; Greeley 1994; Stark and Iannaccone 1994). In brief, we are now certain that verification is required for both the single-line secularization theory, and the forecast claiming that eastern regions of Europe will follow a pattern similar to the western ones (Berger 1999, p. 10). The specificity of CEE must also be reflected in the relations between science and religion.

In my studies the role of regional context is crucial. I concentrate on searching for cultural aspects responsible for the manner in which the question of the science-faith relationship is dealt with on an individual level. I focus on natural scientists from Ukraine and Poland, the countries, which have still been hardly investigated to show 
that other historical and cultural experience may create social mechanisms different from those in the West.

\section{A Few Methodological Remarks}

The significant differences between the CEE countries provide rich material for comparative research on cultural patterns of secularization and therefore the role of science in it. For example, the countries which endured a longer period of forced atheization now experience a deeper secularization process (Yablokov 1979: p. 139). The final balance of this period seems to be determined also by the dominant religion, as Catholicism has suffered losses smaller than Orthodoxy and Protestantism (Pollack and Müller 2006: pp. 24-5; Tomka 2006: p. 51; Borowik 2007: p. 660). The emphasis on religious self-identification and confessional identification as well as church attendance has been distributed differently, thus enabling to establish a typology of CEE countries that distinguishes different patterns of secularization in this region. In this typology, Poland and Ukraine proved to be separate types (Zrinščak 2004).

Poland and Ukraine are neighbouring countries well suited for a comparative study. Both countries had experienced forced sovietisation, but Ukraine had internalized it more effectively. Christianity dominates in both of the states, but they follow different denominations (Eastern and Western) and attitudes towards rationality and knowledge. The apophatic approach of the Orthodox tradition might be an additional factor of impact in the Ukrainian context. Catholic tradition also has its specificity because of its rationalistic theology and historical conflicts with science. Ecklund, Park and Veliz link the high rate of attrition during the scientific work they have detected among Catholic scientists to the historical view of Catholicism as an anti-science (Ecklund et al. 2008).

The religiosity of academia has never been studied in Ukraine, and in Poland there have been three quantitative studies, which describe the lower religiosity of the academics in comparison with the general public (Libiszowska-Żółtkowska 2000; Erenc 2010; Gołąb 2017). However, the factors responsible for these circumstances are still unknown. Is it really dealing with science that negatively impacts the religiosity of the scientists, and if not, what is the factor that determines their religiosity? While searching to answer these questions, I will take a closer look at biographical trajectories of formulating the (un)faith of the researchers within the specific context of Poland and Ukraine.

The analysed semi-structured in-depth interviews were conducted by me in 2013-2015 and included 100 researchers from Poland and Ukraine (25 physicists and 25 biologists in each of the countries) mostly employed by the research institutes 
of the Ukrainian and Polish Academy of Sciences, ${ }^{1}$ which are located in the capital cities of these countries. All of them were recruited using snowball sampling. Focus on biology and physics was already applied in some studies on the academia (Leuba 1916, 1934; Larson and Witham 1998; Ecklund et al. 2016). I selected these disciplines not only because of their key presence in historical debates between science and religion (cf. Ferngren 2000) and the fundamental philosophical balance of certain discoveries and theories, but also bearing in mind the differences in religiousness of scientists belonging to these disciplines, which was proven in many studies (Ladd et al. 1978; Politics of the professoriate 1991; Larson and Witham 1998; Stark and Finke 2000: p. 53). Exploring this circumstance with qualitative tools could broaden the understanding of vehicles weakening faith within the disciplines (cf. e.g. Thalheimer 1973); however in this article no reference to this part of the study has been made.

The importance of research into the religiosity of the academic elite has been repeatedly stressed in view of their impact both within academia and on the broader public, as well as their role in the production of knowledge, institutional change and the shaping of future societal leaders (Schuster and Finkelstein 2006). Current research also indicates they are the most secularized group in the academic sphere (Leuba 1916, 1934; Larson and Witham 1998), while the selection and professional preparation of academic elites seem to lead to their losing religious affiliation (Ecklund et al. 2008: 1806). In my research I focused on a group of elite scientists employed at the Polish and Ukrainian Academy of Sciences, the largest and most highly esteemed research institutions in these countries. I selected both groups of respondents symmetrically, and in the capitals of their countries (Kiev and Warsaw). The samples then reflect the situation of central institutions and cities, which may prove to be more important for Ukraine, with its strong regional divergences of religious patterns, although the concentration of the most important research institutions in Kiev reduces the significance of these differences.

Some studies suggest that to analyse the changes in secularization it is important to explore religious differences in the birth cohorts (Voas and Chaves 2016: 1548; Kaufmann et al. 2012; Zrinščak 2004; Ecklund et al. 2008; Gautiert 1997; Reistma et al. 2012; Molteni 2017). In my research I focused on the professors as they have normally completed all the stages in their careers, their biography is longer, accompanying important historical changes in the countries. The reason for including younger academics in the study was to spot possible generational differences, the verification of which will be the subject of further testing. As a result, the study group included 35 professors or doctors habilitus from Ukraine and 44 from Poland, 9 and 2 PhD holders, 6 and 4 master degree holders respectively. 19 Ukrainians and 21 Poles were born at the turn of the 1930s and 40s, or in the 1940s, 13 Ukrainians

\footnotetext{
1 Several Polish scholars worked in research departments of the top national universities (the Warsaw and Jagiellonian University). Due to supplementing the sample with several new and more extensive interviews, the data obtained may insignificantly differ from the one discussed in the earlier publications (see: Rogińska 2016, 2017).
} 
and 14 Poles in the 1950s, 8 Ukrainians and 8 Poles in the 1960s, 6 Ukrainians and 4 Poles in the seventies and the next decade was the time the youngest respondents (4 and 3 respectively) came into this world. Both groups are predominantly male.

I tried to capture the biographical as well as ideological aspects in the interviews. On the one hand then, I asked my interviewees to remember what were the circumstances surrounding their (un)faith in the supernatural and how it was manifested along science throughout their early childhood, school, university studies and years of research work. On the other, I focused on reconstructing their ideas in individual, existentially crucial issues possibly having both scientific and religious interpretations - such as the rise of the universe and man, the existence of the soul, afterlife, genesis and the essence of morality. In the next part, I am solely concentrating on biographical events.

The statement that academics are less religious than the general public disciplines the researcher to become very sensitive while defining the concept of religiosity. It is obvious that if we define it in a narrow manner, as had been done by the pioneers of the studies on the religiosity of academia (see Leuba 1916) we will obtain lower scores than if we offer a more inclusive definition. My research presents a broad perspective of religiosity. I assume that religious views are those that positively determine the existence of a supernatural factor, the latter being treated in a phenomenological spirit, as something that in the respondent's interpretation comes from the numinous dimension- "different", "mysterious" and goes beyond the scientific state of knowledge. Thus, also the worldviews focused exclusively on the natural order can be classified as religious, if they interpret it in categories typical of faith (such as “design”, "plan”, "spirit”, "miraculousness", “contact", "prayer", "care” etc.).

\section{Historical Background of Ukraine}

When reconstructing the biographical trajectories of the (un)faith of the scholars, we must refer briefly to the historical background within which they were taking place. These contexts were different in Poland and Ukraine, although in both countries there was a period of real socialism, during which religion was combated by communist authorities.

The oldest generation of Ukrainian respondents was born at the turn of the 1940s. While the 1930s in Soviet Ukraine were a period of cruel repressions against the religious worshippers, the Second World War and post-war times were characterized by Stalin's partial withdrawal of the persecution of the Orthodox Church and its incorporation into the political goals of the Soviet Union. However, the situation became more extreme in the mid-1950s, when Nikita Khrushchev launched an extensive anti-religious campaign. At that time, a huge bureaucratic apparatus was created to deal with the atheization of the society, the state opened institutes of scientific atheism and universities introduced appropriate courses. Great importance had been attached to the "scientific and natural propaganda" in the spirit of the "truly scientific communist ideology", i.e. dialectical and historical materialism. The doctrine of scientific atheism was reflected virtually in all university disciplines. The believers were offered "individual" treatment, there were more and 
more denunciations; public shamings of worshippers in collectives, and repressions spread (Гераськин 2009).

In the 1960s, those who had been socialized in tsarist Russia's traditional religiosity, mainly poorly educated elderly people, gradually died away. The materialistic ideology became the norm embracing the socialization of the majority of citizens. At the same time, towards the end of the 1960s and in the 1970s, we saw the Soviet intelligentsia being more and more disappointed in the type of ideology offered by the state. People started searching for religiosity, various doctrines and cults became popular, and the intelligentsia moved towards the Orthodox as a natural alternative to the regime.

The politics of religiosity became more welcome in the Gorbachev perestroika era (see Borowik 2000). A new approach to religion was being formulated: the USSR was a country with a peaceful coexistence of believers and non-believers. The state permitted the celebration of the 1000th Anniversary of the Christianization of Rus (see Borowik 2000), repressions became weaker, the churches were returned to worshippers, the media started cooperating with the clergy. When independent Ukraine was created in 1991, we observed a rapid revival of religious life, which was widely supported by the new politics in the country. The society was open to any of the new religious movements, oriental, syncretic, scientological and esoterical beliefs, but also Neo-Christian denominations-late Protestant communities and new Churches (Дудар 2000). As a result, contemporary Ukraine was one of the most pluralist countries in Europe in terms of religion. Although about $72 \%$ of the population identified themselves as believers and 67\% as Orthodox (belonging to several Ortodox Churches) (Центр Разумкова 2018), the pressure to become religiously socialized in this tradition was much smaller than in the case of Catholicism in Poland. One's religious devotion was a private and not a social matter.

\section{Historical Background of Poland}

The Polish situation was different, mainly due to the much smaller scale of repression against the Catholic Church and the fact that it was supported by a massive number of Poles. Religion had never disappeared from public life; on the contrary, the Church was one of the main social actors on the political scene, always siding with the nation struggling for its independence (Borowik 2010). The strong position of the Church as a dominant religion, an uninterrupted religious tradition, the institutionalized religious socialization (religion classes at school or at parishes) and the inclusion of religion in political struggle had resulted in a noticeable social pressure to be a Catholic in Poland.

The history of communist Poland began in the post-war years. In the second half of the 1940s and until the mid-1950s, the communist government aimed to marginalize Catholicism as an institution that enjoyed the support of society. The autonomy of the Church was then limited, repressive acts were used against the disobedient clergy (the Primate of Poland was interned), there were no more religion classes offered at schools, and Catholic organizations were being closed. It is only when Władysław Gomułka came to power (1956) that politics became gentler for a while: 
interned bishops were released, schools could again provide classes in religious education, new churches were being built, preparations for the 1000th Anniversary of the Baptism of Poland were underway, which greatly stimulated the pastoral work of the church opposing the atheist indoctrination of the youth. The authorities quickly withdrew from these concessions granted to Church, but they failed to limit the mass religiosity of Poles (Noszczak 2008).

In the year of the 1000th Anniversary of the Baptism of Poland (1966) religious ceremonies were held in all of the diocese capitals. Moreover, the Church unofficially supported anti-government student movement in March 1968, while the anticommunist trends displayed by the young encouraged the clergy to intensify pastoral work in the 1970s. General enthusiasm and religious awakening was triggered by the figure of the "Polish" Pope John Paul II (1978) and his pilgrimage to Poland (1979). The Church participated in the anti-communist "Solidarity" movement, and after December 13, 1981, when martial law had been introduced in response to antigovernment unrest in the country, it continued to help the repressed.

Catholicism remained the dominant religion after the collapse of the communist regime in 1989. Nowadays, 92-97\% of Poles declare themselves to be Catholics (CBOS 2015). Religious education has been reintroduced to schools, the Church remains actively involved on the social and political arena. Although Poland remains a highly religious country, one can notice the features that sociologists regard as traces of a slow privatization of religious beliefs and selectivity in the approach to Catholic doctrine (Borowik and Doktor 2001; Marianski 2004; Boguszewski 2012).

\section{Forms of (Non)religious Ideologies}

My further analysis, will not only include the biographical trajectory of formulating the (un)faith of the scholars, but also in how individual forms of such (un)faith develop. The principal forms of the (non)religious ideologies were distinguished on the basis of those sections of interviews in which scholars described the content, intensity and justification of their (un)faith. These categories were based on the factors that most extensively distinguish the ideologies from each other, specific for each of the studied countries. The identification with the institutionalized Catholicism and readiness to accept the doctrine in its entirety were the significant factors for the Polish group, while for the Ukrainians the intensity of the broadly-defined religious practice proved to be decisive.

This data was then encoded and analysed using QDA Miner, a qualitative data analysis software. Further analysis confirmed the high coherence factor of these categories, as the respondents who belonged to them showed similarity in all the studied worldview areas. This made possible developing two typologies, building them around the scale of the severity of the dividing criterion, which gives us the opportunity to combine Ukrainian and Polish weak, medium and strong forms of belief, showing a relative similarity, but not identity in both populations. It is easy to notice that the distinguished forms can be generally discussed in terms of belonging to an institutional religion or religious movement. 


\section{The Ukrainian Group}

In the Ukrainian group, therefore, I distinguish four forms of (non)religious ideologies:

The weak form represents the non-belonging scientists and "minimal" religiosity (Epstein 1999), featuring scarce or non-existent religious practice (24 respondents). The supernatural is seen "between the lines", perceived with a "side view", there is a rejection of institutional religious language aimed rather to capture religious premonitions than stable doctrines. It is worth noticing that such respondents often rely on the existence of a supernatural factor mainly based on scientific observation, speaking about the complexity and harmony of the world, the mystery of quantum effects, etc.

The middle form represents respondents who need a more regular contact with the supernatural, mainly in a ritual and liturgical form (7 persons). They attend services (mostly Orthodox) rarely, but regularly, know simplest prayers, some of them occasionally receive holy communion. They therefore use the institutional resources of religion and so belong to it in their privatized way, but are not affiliated with a parish or religious community, and sometimes even with a specific denomination.

The strong form is represented by 8 scholars who belong to religious communities - affiliated with Orthodox parishes, members of Protestant communities, Jehova's witnesses and two biologists belonging to a quasi-scientific group. They are making continuous efforts to make their faith more profound and participate in the activities of their communities.

11 Ukrainian non-believers mainly called themselves atheists (10 people).

\section{The Polish Group}

In the Polish group the following forms have been distinguished:

The weak form consists of non-belonging believers who have separated from Catholicism while maintaining faith in supernatural forms. They choose faith without affiliation, clearly privatized and individualized ( 5 scholars).

The middle form, selective Catholics, includes 8 of my interviewees. These researchers follow the majority of the truths of faith, call themselves "Catholics", however, some of their beliefs in-sometimes basic - truths of the Catechism have undergone erosion.

The strong form is represented by consistent Catholics (16 people). They are people who have a strong feeling of belonging to the Church, believe in the truths of faith given by it and declare their readiness to accept its doctrine in its entirety.

The Polish group also included 21 non-believers - who called themselves atheists or agnostics, sometimes using both terms interchangeably. 
I will now consider the biographical part of the interviews to see how these ideologies have been developing against the turbulent history of Ukraine and Poland from the mid-twentieth to the beginning of the twenty-first century. ${ }^{2}$

\section{Childhood and Family Socialization in Ukraine}

The social class policy of the Soviet Union created broad career opportunities for people from families that did not belong to intelligentsia-i.e. peasants and members of the working class. This explains a fairly high percentage of scholars from such families. Some of these people kept close contact with the village where their grandparents lived. Most future scientists for the first time encounter the idea of religious tradition-Orthodox, Greek Catholic and Catholic, and in one case Evangelical via the contact with their grandparents.

About half of my respondents speak about their believing grandmothers, who usually profess faith in a traditional manner, pray, keep icons, take their grandchildren to church services and initiate their baptism, often in secret. For older and middle-aged scholars, the figure of the grandmother (and/or grandfather) remains the only religious memory for many years. They return to it today, when their need for religion, more openly expressed in the conditions of religious freedom, is waiting to be appropriately defined.

In the course of their biographical narrative, the older and middle generation present a more ambivalent image of their parents. The vast majority had at least one parent presenting the approach of a non-believer. This was often related to career reasons: non-believing parents were communist party members, senior managers (schools, hospitals), teachers or even party officials. The biographical narratives of the respondents strive to diminish their non-belief: "there are militant atheists, and we were rather not like that" (25f, strong, 1952).

\section{The Ukrainian School}

The period of school education seems to be a period of a total "religious silence" for the Ukrainian scholars. Religion is not present in the memories of the majority of respondents. In the 1940s to the early 1980s the subject of religion does not seem to exist at schools: "at those times the question whether God exists or not, was not discussed at all (...) the years were hard” (2bU, weak, 1940). Children participate in the secular rites of passage - they become pioneers, then Komsomol members.

However, the difference between the Soviet and contemporary schools is clearly visible. The five youngest respondents dwell on the religious subject to a vast extent. Some teachers suggest a religious interpretation of scientific facts. $\mathrm{PhD}$ students are

\footnotetext{
${ }^{2}$ The numbering of respondents includes information on their form of (un)belief, discipline ( $b$ - biologist, $\mathrm{f}$ - physicist) and year of birth.
} 
examining the aspects of their own faith. Although some psychological and sociological studies point to the fact that the ideology forming processes determining whether you will become a believer or a non-believer are already taking place in late adolescence (Beit-Hallahmi and Argyle 1997; Ecklund 2010; Elchardus and Spruyt 2009; Wuthnow 1985; Hardy 1974; Roe 1952), the Ukrainian example shows how important the historical and cultural context is. While the students attending the atheist school had "nothing happening" within the scope of their ideology, the contemporary school's students examine the topic in a profound manner.

\section{The Ukrainian University}

For some respondents of the senior and middle generation, the university remains a period of religious silence, although in other cases we see the first signs of dynamics. Paradoxically, what contributes to it are the courses of scientific atheism. If conducted well, by lecturers who silently sabotage state ideology, the students gain insight to the works of great philosophers against which the scientific materialism ranks rather poorly: "They were quite reasonable people who gave lectures in philosophy (...) some enlightened people. And it was at the university that [my consciousness] was awakened and I saw that not everything is so simple" (8b, weak, 1955). The clash with natural knowledge provides some of the respondents with foundations of the future scientific faith: "We did not call [harmony in nature] the Divine order, but we had a sense that this order had already existed" (9b, weak, 1939).

As I have already mentioned, the late 1960s and 1970s are characterized by increased interest in various religious doctrines. The latter might have been experienced by these of my respondents who were students or Ph.D. candidates in the 1970s. The National University of Kyiv is a fertile soil promoting groups of friends, who gather to speak on the philosophical, artistic and literary subjects. There are also occasional attempts to approach religious topics that so far do not end in faith, but already undermine scientific atheism: "From the beginning of my student years I was interested [the philosophy of Russian cosmism]", "people dealing with the cosmos are trying to answer the question about the essence of being (...), where do we come from, what is our destiny? (...) this is a philosophical question, but also a religious question" (8f, weak, 1942). For the time being, these "questions", "feelings" are still in the process of emerging. On the other hand, the younger respond-

ents, who were studying during the post-Soviet times, not only ask the religious questions at this stage of life, but are also ready to provide clearly defined answers.

\section{A Response to State Atheism}

Although we do encounter a group of talented lecturers, university still remains the time of the Soviet ideology predominance manifested in the form of compulsory courses in Marx-Leninist philosophy. They use the scientific ideas to show 
the superstitious character of religion. Today, almost none of my interviewees mentions this experience as important. Emphasizing the insignificance of scientific atheism becomes the basic narrative strategy. It is "childish", "ridiculous" (19f, weak, 1955), and above all boring. The typical "I had a C in Marxist-Leninist philosophy" is the expression of a passive resistance to the regime: "I did not care, so I hardly passed the course. I had a gap because of this and was offended" (25f, strong, 1952). However, the presence of ideology cannot be ignored if one wants to pursue an academic career. To become more and more prominent in this area one must become a member of the party. In this situation, becoming a party member is merely a utilitarian and pragmatic strategy: "I was a member of this criminal organization (the party) for fifteen years. They forced me to join (...) you either become a party member or give up the academia” (19f, weak, 1955).

\section{Religious Revival After Perestroika}

Regardless of the age at which my respondents are during the events at the turn of the 1980s, they play a decisive role in shaping their current views on religious topics. 29 respondents speak about the first and/or critical reflections on the supernatural after the perestroika of 1985. The whole plethora of interpretations of the supernatural takes us to the religious polyphony present in the Ukrainian society, which started at the turn of the 1980s and continued throughout the entire 1990s. Some of the new religious movements that are spreading at that time are directly related to science. This may explain why my interviewees interpret the scientific terms ("energy", "field", "force") in a religious manner. The diversity of the religious offer is best illustrated by a brief overview of the episodes that took place in the lives of respondents during this period. They concern all forms of religiosity.

Religion of the strong and middle form is impacted by the charismatic clergy, and often occurs as a consequence of meeting a supportive community. It is taken over from religious adepts and groups that convey religious competence and spread stable religious doctrine. And so, in the early 1990s, a theoretical physicist (then in his thirties) speaks with a believing colleague, a physicist from Moscow. In consequence of these conversations he turns to the Bible and finds the parable of the sower, which impresses him greatly. This is how his path to Orthodoxy begins, which results in deep faith and regular practice (today a professor, 25f, strong, 1952). The explosion of the Chernobyl nuclear reactor in 1986 is interpreted by a 32-year-old biologist, today a professor, as the Wormwood Star foretold in the Apocalypse, which encourages him to return to the familiar Christian Orthodox Church (4b, strong, 1951). His colleague, then over fifty, starts his religious search and "begins bouncing between one religion and another, read different pieces of literature, go to different people". Finally, he meets Jehovah's Witnesses (11f, strong, 1940).

Similar conversions also concern the younger generation, born in the 1970s, whose last years of school went by in religious freedom. It was at the turn of the 1980s that the then student, and today doctor of biology, reads the texts of Alexander Mien, an Orthodox priest popular among the intelligentsia, which convinces him that the story of Christ is true. He becomes a believer of the Ukrainian Orthodox 
Church (15f, middle, 1972). Another student joins the Protestant community at that time (14f, strong, 1975).

After the perestroika, the weak ideologies also crystallize. It is at this time, the five respondents are experiencing ground-breaking, tragic or mysterious events that they interpret as manifestations of the presence of the supernatural in their lives. But also those who build their religious insights on scientific content-to which they had already had access-only now begin to interpret it in terms of the supernatural. Today's scholar, a professor of biology, who is about 40 years old in late 1980s, reads the philosophical works of great physicists - Einstein, Bohr, and Heisenberg. Today he thinks that it was Einstein, who converted him (8b, weak, 1950). Gradually, "with the development of biochemistry", the biology professor is becoming convinced that the amazingly "organized" action of the cell points to the "idea of creation" (9b, weak, 1939). The science "helps to put together" the religious ideas of a professor of theoretical physics who, from the period of his childhood, has had the feeling that "he is a part of the whole" (19f, weak, 1955).

It is interesting that a group of non-believing scholars, consisting of "convinced atheists" and one agnostic, did not experience any ideological transformation in the 1990s (I ignore the youngest Ph.D. student in biology, an atheist [23b, non-believer, 1986]). As I mentioned, the youngest generation is formulating their approach during the period of their studies. They experience an entirely different cultural situation than their older colleagues. However, they should still be considered as a part of the group of respondents, whose religious views are being developed in the independent Ukraine.

\section{Childhood and Family Socialization of Poles}

The Polish sampling, unlike the Ukrainian one, mainly includes respondents having a background in the intelligentsia. At least 39 people from all age groups come from the city, and the countryside appears in the narrative very rarely. The most clearlycut relationship of the current religious standing of my respondents with the faith of their parents can be seen in the groups of strong and middle forms (respectively 10 out of 16 consistent and 4 out of 8 selective Catholics), who had both believing parents. However, also 16 of 21 non-believing respondents come from families with at least one believing parent, which means that with time they have lost their family faith.

Early religiosity of the majority of the respondents can be described as "child's faith". It is rather mindless, naïve, which is now ironically commented on by the non-believers: "Being a small child, I was expected to pee, pray, and go to sleep in the evening" (25f, non-believer, 1952). Only the consequent Catholics from the intelligentsia remember some religious conversations between adults "these questions that a man must face (...) I was confronted with very early at home" (21b, strong, 1938). But it is more common not to speak about faith in the Polish families.

The role of grandmothers and grandfathers in the religious education of Poles is not as significant as in the case of the Ukrainians, although they are mentioned as 
being the first people introducing my respondents into the ritual dimension of religious life. The Polish scientists remember it was rather the teachers of religion and parents, who dominated in this respect. The prevalence of religious practice among the Polish children results from the "natural" sense of belonging to the Catholic church during the communist period. This "natural sense" is positively assessed by scholars with a strong religious ideology: "there was a religious tradition at home (...), so I chose [to go to religion classes and attend church services]" (22b, strong, 1964). The nonbelievers are rather negatively inclined towards this, especially if the sense of religiosity expressed by their parents was not particularly convincing for them.

\section{The Polish School}

In contrary to the Ukrainian scholars, the Poles associate their school period with a variety of religious memories. This is mainly due to religious classes held at school or in parishes. It is perceived in a similar manner by both, the believers and nonbelievers, however the non-believers typically diminish their religious awareness at the times of school: "everyone attended [the church] in the same way like everyone walked in the May Day parade” (10f, non-believer, 1949).

In the times of the PPR, non-believing is often associated with communism, and Catholic religiosity with the anti-communist resistance. Children had been involved in this struggle from the very beginning. They felt that they have to take sides: "Then, you could either be a communist or a Catholic" (2f, non-believer, 1964).

Children from religious families naturally adopt the rebellious attitudes of their parents: "I went to school in the Stalinist times (...), [precisely because] it was illegal (...), it was obvious we attended the religion classes" (20b, middle, 1939). The students then participate in the resistance gestures, and in return are gratified by the society ( "going to church somehow manifested a type of defiance", "I felt better just because I attended the church services" (17f, strong, 1955) and the sense of bonding with the others "we were going in a group and simply by going to religion classes you felt ennobled" (16f, strong, 1959). But those who had already found themselves on the secular side, felt a strong religious pressure: "It was the early 1960 s (...) I went to a grade school, which was enormous, there were 1,100 students, and there was one child in all this great school who did not attend religion classes. And this child was extremely humiliated and persecuted by his colleagues, teachers and parents of other students". According to this respondent, a non-believer in Poland has been permanently stigmatised as a communist and an "evil man" (1f, non-believer, 1955).

While the Ukrainians from my sampling (apart from a few Ph.D. candidates) meet their religious authorities when already adults, the majority of Poles experience this moment as pupils at school. In this respect believers once again have more luck: "I came across a wonderful priest (...) who was simply a man of God. At that time, the Church perceived itself as an opposition to the dirty world, which it was at the time, but he was the epitome of opposition himself - as a person" (22b, strong, 1964). The school and university students of the 1970s (as well as their older colleagues) treat the election of the Polish Pope as a religious experience. At present a non-believer, a researcher in astrophysics was at that time "deeply religious", "it 
was the time the election of the Polish Pope was announced, and it was our Pope, and me and my dad went on our first pilgrimage to Poznań. It was all part of a one whole". Another religious experience is the death of father Popiełuszko, murdered by the communists in 1984 (9f, non-believer, 1968). ${ }^{3}$

The first ideological reflections occur in the grade and, especially, secondary school. The first existential questions are being posed. A biology scholar raised in a non-believing family goes through a "crisis" when he becomes aware of human mortality: "I replaced the [religious faith] with some kind of scientific faith, some kind of machine immortality, which [will transform] my brain into a computer" (2b, non-believer, 1963). Teenagers are confronted with their own fears related to the religious doctrine: "It was hard for me to believe that a creator could be so ruthless" (25f, non-believer, 1952). They begin to search for literary sources, start reading: "my entire religious education was based on reading a lot, here and there" (20f, non-believer, 1956).

And again, persons who are still religious now, received support from wise religion teachers or intelligent parents: "I had my ontological doubts and decently conducted religion classes gave me the answers" (20b, middle, 1939). On the other hand, the current non-believers experience disappointments in the period of childhood and teenage years. Meetings with potential authorities turn out to be unsuccessful: "We had our parish priest come to a religion class and speak about evolution. And he spoke such nonsense!”, “and I was fully aware of this, only at that time, this parish priest was someone of an authority", "I remember being so ashamed of him". The respondent does not rule out that it was one of the factors that caused his gradual departure from faith (10f, non-believer, 1949).

The subject of the relationship between science and religion is encountered by the Polish scholars very early, sometimes even in grade schools, along with the first interest in the subject of science. At the same time, it is the beginning of the later naturalistic and sceptical rationalistic thinking and the inclinations towards nonbelieving: "I have always been rationalizing it all, as long as I can remember" (20f, non-believer, 1956). All these proclivities reach a peak in the teenage periodaround 14-17 years of age, when the young people go through the teenage crisis, reformulating their faith or departing from it: "I did not accept what others told me, I just wanted to understand myself. And I saw no reason to continue attending [religion classes]" (3f, non-believer, 1948).

\section{Ideological Crisis}

Only with certain reservations can the teen crisis be called a real "rebellion" against faith. In fact, some people, mostly consistent Catholics, do not experience any difficulties with faith throughout their lives. But also people of selective faith rarely describe crisis in this manner: "This (...) sort of rebellion, has never been a problem

\footnotetext{
${ }^{3}$ Father Jerzy Popiełuszko-a charismatic opposition clergyman murdered by the communist authorities in 1984, today beatified by the Catholic Church.
} 
to me. I've never had one" (11b, middle, 1949), erosion gets in unnoticed, and often this process does not subside in adulthood. In non-believers, we are rather dealing with the maturation of their non-belief: "not rapidly at all", "slowly, step by step" (3f, non-believer, 1948). Weak believers lose the Catholic faith in a similar manner, as they come to realize that "this is all made up" (7f, weak, 1948). This process starts around the age of 14-17 and ends in the last few years of high school or, less commonly, in the first few years of university. This tendency is probably universal, associated with the typical dynamics of personality maturation, as similar narratives are found among the non-believers in the youngest generation: "I don't see in myself any critical point that would make me change the way I feel about religion", "this was more of a continuous process", "as I went into adolescence" (5b, non-believer, 1980). As many as 21 respondents experienced this process in a typical way (15 while still in school, 6 in university and grad school). It was then that 16 of these believers with their "childhood faith", made the final decision to give up on their faith.

During this period the final verification of the Church's communication on morality takes place: "I decided to become a saint because if you believe in God, you have to strive for sanctity. I soon realized, though, that I was the only sucker there, that no one around me was actually striving to become a saint [...] and so I came to the conclusion that they definitely don't believe", "and if most people don't believe, why should I?" (1f, non-believer, 1955). Future non-believers get disappointed by the impossibility of miracles and abandon theodicy. In the end, they stop religious practices, and stop attending religion classes: "Ever since grade eight [...] I've had nothing to do [with religion]” (10f, non-believer, 1949).

Although 16 consistent and selective Catholics have never gone through a crisis (with most of them [12] having been raised by parents who were both believers), even some of them struggle during that time with the founding ideological dilemmas. Successful resolution of these dilemmas is not only important for maintaining religiousness, but also for maintaining its specific form (strong or middle, consistent or erosive) and the questions posed during the remainder of their religious lives. The last few years of school are therefore crucial in terms of shaping (non)religious attitudes.

\section{University and Doctoral Studies in Poland}

Studies at the university start just after this turbulent period. They involve new experiences, hard work and entertainment for these young people. For all but 6 people (who are experiencing a moment of doubt right now or a few years later), their ideological ups and downs are being pushed aside for a moment: "We had so much course work that we didn't really have that much time for philosophical discussions" (8b, non-believer, 1977). Separation from the family and the parish as a result of going away to university contributes to the discontinuation of religious practices: "The life I had here wasn't generally very Catholic. Because you have to be struggling all the time" (9f, non-believer, 1968). Scholarships, internships, doctoral fellowships allow them to notice the diversity of beliefs, which boosts the scepticism 
towards the Catholic religion even more. And when they reject Catholicism, they often reject the belief in the supernatural.

However, strong religious experiences that bring the whole society together interfere, for a moment, with the trajectory of faith loss. The election of a Pole as the pope, the rise of the political opposition, and the imposition of martial law affect all the (non)religious types. The religious trajectory of a country also affects those who no longer believe or are losing the Catholic faith in various groups: "When martial law was introduced, I did actually go to my local parish but it was more for company than because of my spiritual needs, but I did have contact with the parish community. This was a prelude to an episode in my life when I wanted to return to the Church community", "in the 1980s I tried to make myself need to believe" (10f, non-believer, 1949). "I took confirmation quite late, I was about 30 years old then. It was a very mature choice on the tide of exaltation associated with the death of Father Jerzy Popietuszko. I attempted to return to the Church then and I even thought that this time I'd make it for good. But it turned out that I hadn't' (14b, weak, 1955).

\section{Adulthood and Scientific Work of Poles}

In adulthood, when the scientists deal with professional science, the Polish group demonstrates the deepening and strengthening (also with scientific content) of the existing ideological models of all types, both religious and non-religious. The major internal "battles" had already been fought, and now "everything was stable" (3b, strong, 1938), "the same" (2b, non-believer, 1963). Those on their way to nonbelieving, before the religious boom in the 1970s and 80s, succumbed again to the dynamics of non-belief. It was facilitated by the change of the Catholic Church's role: the Church stopped being identified with anti-communist resistance but retained its active role as a political player, which is often negatively perceived in Poland. More mature questions arise regarding the relationship between science and religion, the believers try to work towards explaining their faith with scientific facts they are aware of, while the non-believers perfect arguments to support the non-faith.

\section{Conclusions}

Let us now try to draw conclusions that would be important for the question we posed at the beginning: does science negatively affect the religiousness of scientists from Poland and Ukraine, and if not, what factor has impact on their religiousness? We can, already at this point, provide the answer: its role is more complementary than decisive. Interestingly, in cases of Ukrainian scientists, initially non-believers, this role is positive and shapes the widespread form of weak religiousness, however, also supporting strong synthetic world-views. Being a reservoir of contents from which religious ideologies draw, science appears in Ukrainians' lives relatively late, during their scientific work. Meanwhile in Poland, scientific content, or rather a 
vague conviction that there is a conflict between science and religion, is most often used by future scientists (weak form and non-believers) who do not have anything to do with science as early as in their adolescence to support the increasing nonbelief. However, once the ideology is established, and the Polish scientist carries out professional research, thus being in close contact with science, science helps them strengthen their argumentation in favour of an existent solution to the religious question. Science is now equally used by religious and non-religious scientists of all forms of belief.

If science is not the decisive factor, then what plays the most important role in shaping (non)religious world-views? These factors seem different in the two populations.

According to the interviews, religion in the Soviet Ukraine had not been completely eradicated. It smouldered in various forms: in the interviews, it appears as ritual religiousness of grandparents and students' conversations. However, none of these elements seem to be solely responsible for the future religiousness of the scholars. A similar conclusion seems evident regarding the transmission of religious opinions by older generations. Although most scientists had non-believing parents, today they profess religious ideologies. None of the respondents mentioned any major influence this fact had on their own approach. On the contrary, they belittled the significance of non-faith of their fathers and mothers, emphasizing its pragmatic or career-related nature.

The only important event that seems to be crucial for all the religious forms is the fall of the Soviet Union and the religious revival in Ukraine. It is then that the neverbelieving scientists start thinking about God or other forms of the supernatural. They find it in the nature, in their own lives, in communities and places of religious worship. The new social and political situation affects them as students and as mature scientists irrespective, it seems, of age. 20 former non-believing scientists convert to religious faith at that time: 14 of them gain a weak conviction that the supernatural power exists, four start attending church services more regularly and are now qualified as middle type believers, another two become members of the religious communities (strong faith). Religious ideologies of the 8 respondents, who preserved in Soviet times some connection with the religious tradition of their childhood, take shape now being strengthened by a religious practice. Four of them become middle, another four strong believers.

Many of these scholars directly speak of religious revival in the country as of a necessary context for their conversion. But even if the emergence of faith is less dramatic, gradual, its timing is significant. The typical developmental dynamics responsible for the shaping of the religious ideology is, in a way, anchored in the Soviet period and "switches on" in the setting of religious freedom. In student years, when older scientists usually had no significant thoughts about it, today's Ukrainian Ph.D. students already make fundamental decisions related to their ideology. The cultural context in the Soviet Ukraine did not give older colleagues sufficient substratum for such certainty. It is noteworthy that the religious trajectory of the Ukrainian society follows from non-belief towards belief, and overlaps with the faith trajectory of the Ukrainians who convert with their whole country. 
In Poland, these processes are different. On the one hand, in cases of strong and medium religious types, the strong religiousness of the parents is a factor that plays a positive role in maintaining the Catholic faith. Strong religious socialization, intelligent conversations with the child about the faith, meetings with respected and helpful religious authorities - in other words, all that can provide a good religious social environment-helps maintain that faith. It's worth mentioning, that if the religious life of a scientist was affected by a charismatic personality, the scientific content played a lesser role in conversion and was predicated by the personal charisma of an authority.

The religiousness of the Poles is often stable. 16 of the Catholics have never experienced significant religious crisis. As many as 25 people, at present both believers and nonbelievers show no shifts in the intensity of their (un)faith. On the other hand, the Polish dynamics, if visible, mirrors the Ukrainian: in many cases, these are trajectories from faith towards non-faith, which strengthen in the last few years of high school, with the typical development of personality and ideology maturation seeming to be responsible for the decisions related to the ideology. Therefore, this is not a conversion dynamic but a dynamic of the loss of "childhood faith".

The last few years of school and the first few years of university seem crucial. It is at that time that three people lose their Catholic faith (now weak believers), and as many as 16 not only give up on their childish Catholicism but stop believing in the supernatural powers in general (now non-believers). Professional work as a scientist is not significant here (only 1 respondent, today religious, mentioned a crisis of faith occurring during his professional career). The age, the discipline or the social background also seem to play little role, although this conclusion would need to be investigated in a quantitative study. So in the case of Poland, rather than talking about the reasons for converting, we should be talking about the causes of a loss of faith, which clearly does not occur as impacted by professional science, but takes place earlier and seems to result from the scientist's personality (a rationalistic, sceptical, empirically-oriented mind), whose roots have not been identified in the present study, as well as from unhelpful religious environment. Elements of confrontation of faith with science are, however, noticed in those respondents still before they acquired scientific knowledge.

The results generally show that the social impact of science, colliding with different forms of religion and historical events, follow the paths which are specific to each country. Therefore, while there are no grounds to talk about the universal role of science in secularization processes, there are many culturally conditioned models of interaction between science and religion. Although most debates about science and religion are still inclined to operate on the assumption of systemic knowledge conflict between them (Evans 2018), the results of this study suggest that cultural and social mechanisms play an enormous role in the relations between the two fields.

Open Access This article is distributed under the terms of the Creative Commons Attribution 4.0 International License (http://creativecommons.org/licenses/by/4.0/), which permits unrestricted use, distribution, and reproduction in any medium, provided you give appropriate credit to the original author(s) and the source, provide a link to the Creative Commons license, and indicate if changes were made. 


\section{References}

Barker, E. 1998. State Imposed Secularism: Yet Another Dimension? In Secularization and Social Integration: Papers in Honor of Karel Dobbelaere, ed. J. Billiet, R. Laermans, and B. Wilson, 190-210. Leuven: Leuven University Press.

Beit-Hallahmi, B. 2015. Explaining the Secularity of Academics: Historical Questions and Psychological Findings. Science, Religion and Culture 2(3): 104-119.

Beit-Hallahmi, B., and M. Argyle. 1997. The Psychology of Religious Behaviour, Belief, and Experience. London and New York: Routledge.

Bello, F. 1954. The Young Scientists. Fortune 49: 142-143.

Berger, P.L. 1999. The Desecularization of the World: A Global Overview. In The Desecularization of the World: Resurgent Religion and World Politics, ed. P.L. Berger, 1-18. Washington, D.C.: Grand rapids.

Berger, P.L. 2008. Secularization falsified. First things 180: 23.

Boguszewski, R. 2012. Religijność i moralność w społeczeństwie polskim - zależność czy autonomia? Studium socjologiczne. Toruń: wyd. Adam Marszałek.

Borowik, I. 2000. Odbudowywanie pamięci: przemiany religijnew Środkowo-Wschodniej Europie po upadku komunizmu. Kraków: Nomos.

Borowik, I. 2007. The Religious Landscape of Central and Eastern Europe After Communism. In The Sage Handbook on Sociology of Religion, ed. J.A. Beckford and N.J. Demerath III, 654-669. London: Sage.

Borowik, I. 2010. Why Has Religiosity in Poland Not Changed Since 1989? Five Hypotheses. Politics and Religion 3: 262-275.

Borowik, I., and T. Doktor. 2001. Pluralizm religijny i moralny $w$ Polsce. Raport z badan. Kraków: Nomos.

Bourget, D., and D. Chalmers. 2013. What Do Philosophers Believe? Philosophical Studies 170(3): $465-500$.

Casanova, J. 2008. Public Religions Revisited. In Religion: Beyond the Concept, ed. H. de Vries, 101119. New York: Fordham University Press.

CBOS. 2015. Zmiany w zakresie podstawowych wskaźników religijności Polaków po śmierci Jana Pawła II. http://www.cbos.p1/SPISKOM.POL/2015/K_026_15.PDF. Accessed 17 May 2018.

Ecklund, E. 2010. Science vs. Religion: What Scientists Really Think. Oxford: Oxford University.

Ecklund, E., D.R. Johnson, ChP Scheitle, K.R. Matthews, and S.W. Lewis. 2016. Religion Among Scientists in International Context: Methods and Initial Results from a New Cross-National Survey of Scientists. Socius: Sociological Research for a Dynamic World 2: 1-9.

Ecklund, E., J. Park, and P. Veliz. 2008. Secularization and Religious Change among Elite Scientists: A Cross-Cohort Comparison. Social Forces 86(4): 1805-1840.

Ecklund, E., and Ch. Scheitle. 2007. Religion Among Academic Scientists: Distinctions, Disciplines, and Demographics. Social Problems 54: 289-307.

Elchardus, M., and B. Spruyt. 2009. The Culture of Academic Disciplines and the Sociopolitical Attitudes of Students: A Test of Selection and Socialization Effects. Social Science Quarterly 90: $445-460$.

Epstein, M. 1999. Minimal Religion. Russian Postmodernism: New Perspectives on Post-Soviet Culture (with Alexander Genis and Slobodanka Vladiv-Glover), Studies in Slavic Literature, Culture, and Society, vol. 3, 163-171. New York, Oxford: Berghahn Books.

Erenc, J. 2010. Religijność i tolerancja. Stosunek do wiary pracowników naukowych Uniwersytetu Gdańskiego. Przeglad Religioznawczy 3: 123-143.

Evans, J. 2018. Morals Not Knowledge. Recasting the Contemporary U.S. Conflict Between Religion and Science. Oakland: University of California Press.

Ferngren, G. 2000. The History of Science and Religion in the Western Tradition. New York: Garland Publishing.

Froese, P. 2004a. Forced Secularization in Soviet Russia: Why an Atheistic Monopoly Failed. Journal for the Scientific Study of Religion 43(1): 35-50.

Froese, P. 2004b. After Atheism. Sociology of Religion 65(1): 57-75.

Gautiert, M. 1997. Church A Endance and Religious Belief in Postcommunist Societies. Journal for the Scienti c Study of Religion 36(2): 289-296. 
Gołąb, A. 2017. Belief and unbelief in God among Polish scholars and their views on the relationship between science and religion. Roczniki Psychologiczne 20(1): 81-97.

Greeley, A. 1994. A Religious Revival in Russia? Journal for the Scientific Study of Religion 33: 253-272.

Gross, N., and S. Simmons. 2009. The Religiosity of American College and University Professors. Sociology of Religion 70: 101-129.

Habermas, J. 2008. A "post-secular" society-what does that mean? https://www.resetdoc.org/story /a-post-secular-society-what-does-that-mean. Accessed 11 Feb 2019.

Hardy, K.R. 1974. Social Origins of American Scientists and Scholars. Science 185: 497-506.

Kaufmann, E., A. Goujon, and V. Skirbekk. 2012. The End of Secularization in Europe? A Socio-Demographic Perspective. Sociology of Religion 73(1): 69-91.

Ladd, E., S. Lipset, and M. Trow. 1978. Carnegie Commission National Survey of Higher Education: Faculty study subsample, 1969. ICPSR 7078.

Larson, E., and L. Witham. 1998. Leading Scientists Still Reject God. Nature 394: 313.

Leuba, J. 1916. The Belief in God and Immortality: A Psychological, Anthropological and Statistical Study. Boston: Sherman, French \& Co.

Leuba, J. 1934. Religious beliefs of American scientists. Harper's 169: 292-300.

Libiszowska-Żółtkowska, M. 2000. Wiara uczonych. Esej mocno osadzony w empirii. Kraków: Zakład Wydawniczy Nomos.

Mariański, J. 2004. Religijność społeczeństwa polskiego w perspektywie europejskiej. Próba syntezy socjologicznej. Kraków: Nomos.

Molteni, Francesco. 2017. Religious Change among Cohorts in Eastern Europe: A Longitudinal Analysis of Religious Practice and Belief in Formerly Communist Countries. Religion and Society in Central and Eastern Europe 10(1): 35-53.

Müller, O. 2011. Secularization, Individualization, or (Re)vitalization? The State and Development of Churchliness and Religiosity in Post-Communist Central and Eastern Europe, Religion and Society in Central and Eastern Europe 4(1): 21-37.

Norris, P., and R. Inglehart. 2004. Sacred and Secular: Religion and Politics Worldwide. Cambridge: Cambridge University Press.

Noszczak, B. 2008. Polityka państwa wobec Kościoła rzymskokatolickiego w Polsce w okresie internowania prymasa Stefana Wyszyńskiego. Warszawa: IPN.

Pawluczuk, W. 2014. Oblicza Wiary. Kraków: Nomos.

Pew Research Center. 2009. Public Praises Science; Scientists Fault Public, Media. http://www.pewforum.org/2009/11/05/scientists-and-belief. Accessed 17 May 2018.

Politics of the professoriate. 1991. Public Perspective. The American Enterprise 2(4): 86-87.

Pollack, D., and O. Müller. 2006. Religiousness in Central and Eastern Europe: Towards Individualization? In Religions, Churches and Religiosity in Post-Communist Europe, ed. I. Borowik, 22-36. Krakow: Nomos.

Pollack, D., and G. Pickel. 2007. Religious Individualization or Secularization? Testing Hypotheses of Religious Change- the Case of Eastern and Western Germany. British Journal of Sociology 58(4): 603-632.

Reistma, J., B. Pelzer, P. Scheepers, and H. Schilderman. 2012. Believing and Belonging in Europe: Cross-National Comparison of Longitudinal Trends (1981-2007) and Determinants. European Societies 14(4): 611-632.

Roe, A. 1952. The Making of a Scientist. New York: Dodd, Mead.

Rogińska, M. 2016. Science, Religion, and the Meaning of Life and the Universe. "Amalgam" Narratives of Polish Natural Scientists. Zygon: Journal of Religion and Science 4: 904-924.

Rogińska, M. 2017. Czy nauka zagraża wierze? Biograficzne uwarunkowania wiary ukraińskich przyrodników. Studia Socjologiczne 3(226): 71-97.

Schuster, J., and M. Finkelstein. 2006. The American Faculty: The Restructuring of Academic Work and Careers. Baltimore: Johns Hopkins University Press.

Stark, R. 1999. Secularization, R.I.P. Sociology of Religion 60(3): 249-273.

Stark, R., and R. Finke. 2000. Acts of Faith: Explaining the Human Side of Religion. Berkeley, CA: University of California Press.

Stark, R., and R. Iannaccone. 1994. A Supply-Side Reinterpretation of the "Secularization" of Europe. Journal for the Scientific Study of Religion 33(3): 230-252.

Stark, R., R. Iannaccone, and R. Finke. 1996. Religion, Science, and Rationality. The American Economic Review 86: 433-437. 
Thalheimer, F. 1973. Religiosity and Secularization in the Academic Professions. Sociology of Education 46: $183-202$.

Tomka, M. 2006. The Non-Religious. In Eastern European Religion, ed. E. Révay and M. Tomka, 103120. Budapest-Piliscaba: Pázmány Társadalomtudomány.

Turner, B. 2010. Religion in a Post-secular Society. In The new Blackwell Companion to the Sociology of Religion, ed. B.S. Turner, 649-667. Malden, MA: Wiley-Blackwell.

Vaughan, T., D. Smith, and G. Sjoberg. 1966. The Religious Orientations of American Natural Scientists. Social Forces 44: 519-526.

Voas, D., and M. Chaves. 2016. Is the United States a Counterexample to the Secularization esis? American Journal of Sociology 121(5): 1517-1556.

Wuthnow, R. 1985. Science and the Sacred. In Sacred in a Secular Age, ed. P.E. Hammond, 187-203. Berkeley: University of California Press.

Yablokov, I. 1979. Sociologija religii. Moskow: Mysl.

Zrinščak, S. 2004. Generations and Atheism: Patterns of Response to Communist Rule among Different Generations and Countries. Social Compass 51(2): 221-234.

Центр Разумкова. 2018. "Релігія і Церков в Українському суспільстві: соціологічне дослідження. http://razumkov.org.ua/uploads/article/2018_Religiya.pdf. Accessed 17 May 2018.

Гераськин, Юрий. 2009. Из истории хрущевского наступления на Русскую Православную Церковь. Новый исторический вестник 19: 71-79.

Дудар, Филипович. 2000. Дудар, Надія і Людмила Филипович. 2000. Нові релігійні течії: український контекст. Київ: Наукова думка.

Publisher's Note Springer Nature remains neutral with regard to jurisdictional claims in published maps and institutional affiliations. 